Keywords: cell-free DNA; plasma; quantitative biomarker; non-small-cell lung cancer; chronic respiratory inflammation; real-time PCR

\title{
Cell-free DNA levels in plasma of patients with non-small-cell lung cancer and inflammatory lung disease
}

\author{
A Szpechcinski ${ }^{*}, 1, \mathrm{~J}$ Chorostowska-Wynimko ${ }^{1}, \mathrm{R}$ Struniawski ${ }^{1}, \mathrm{~W}$ Kupis ${ }^{2}, \mathrm{P}$ Rudzinski ${ }^{2}$, R Langfort ${ }^{3}$, \\ E Puscinska ${ }^{4}$, P Bielen $^{5}$, P Sliwinski $^{5}$ and T Orlowski ${ }^{2}$ \\ ${ }^{1}$ Department of Genetics and Clinical Immunology, National Institute of Tuberculosis and Lung Diseases, 26 Plocka Street, \\ 01-138 Warsaw, Poland; ${ }^{2}$ Department of Thoracic Surgery, National Institute of Tuberculosis and Lung Diseases, 26 Plocka \\ Street, 01-138 Warsaw, Poland; ${ }^{3}$ Department of Pathomorphology, National Institute of Tuberculosis and Lung Diseases, 26 Plocka \\ Street, 01-138 Warsaw, Poland; ${ }^{4} / l$ Department of Lung Diseases, National Institute of Tuberculosis and Lung Diseases, \\ 26 Plocka Street, 01-138 Warsaw, Poland and ${ }^{5}$ V Department of Lung Diseases, National Institute of Tuberculosis and Lung \\ Diseases, 26 Plocka Street, 01-138 Warsaw, Poland
}

Background: The analysis of plasma cell-free DNA (cfDNA) is expected to provide useful biomarkers for early diagnosis of nonsmall-cell lung cancer (NSCLC). However, it remains unclear whether the intense release of cfDNA into the bloodstream of NSCLC patients results from malignancy or chronic inflammatory response. Consequently, the current diagnostic utility of plasma cfDNA quantification has not been thoroughly validated in subjects with chronic respiratory inflammation. Here we assess the effect of chronic respiratory inflammation on plasma cfDNA levels and evaluate the potential clinical value of this phenomenon as an early lung cancer diagnostic tool.

Methods: We measured plasma cfDNA concentrations in 50 resectable NSCLC patients, 101 patients with chronic respiratory inflammation (chronic obstructive pulmonary disease, sarcoidosis, or asthma) and 40 healthy volunteers using real-time PCR.

Results: We found significantly higher plasma cfDNA levels in NSCLC patients than in subjects with chronic respiratory inflammation and healthy individuals $(P<0.0001)$. There were no significant differences in plasma cfDNA levels between patients with chronic respiratory inflammation and healthy volunteers. The cutoff point of $>2.8 \mathrm{ng} \mathrm{ml}^{-1}$ provided $90 \%$ sensitivity and $80.5 \%$ specificity in discriminating NSCLC from healthy individuals (area under the curve $(A \cup C)=0.90$ ). The receiver-operating characteristics curve distinguishing NSCLC patients from subjects with chronic respiratory inflammation indicated $56 \%$ sensitivity and $91 \%$ specificity at the $>5.25-\mathrm{ng} \mathrm{ml}^{-1}$ cutoff $(\mathrm{AUC}=0.76$ ).

Conclusions: We demonstrated that elevated plasma cfDNA levels in NSCLC resulted primarily from tumour development rather than inflammatory response, raising the potential clinical implications for lung cancer screening and early diagnosis. Further research is necessary to better characterise and identify factors and processes regulating cfDNA levels in the blood under normal and pathological conditions.

Lung cancer is the leading cause of cancer deaths worldwide. The majority of patients are diagnosed late with local or systemic advanced disease (stage III or IV), when the 5-year survival rate is $<5 \%$. Over half of subjects with lung cancer die within 1 year of being diagnosed (Siegel et al, 2012). Therefore, there is a great demand for new diagnostic and treatment options based on specific biomarkers, preferably detectable in tumour surrogate specimens derived by non-invasive procedures. The discovery of

*Correspondence: A Szpechcinski; E-mail: a.szpechcinski@igichp.edu.pl

Received 1 February 2015; revised 14 May 2015; accepted 26 May 2015; published online 30 June 2015

(c) 2015 Cancer Research UK. All rights reserved 0007-0920/15 
extracellular DNA circulating in blood, so called cell-free DNA (cfDNA), may greatly impact molecular diagnostics of lung cancer patients due to simple, non-invasive access to genetic material detectable in plasma and serum by sensitive molecular biology techniques.

The precise mechanism by which cfDNA is released into the bloodstream remains unknown. Several authors have suggested that cfDNA is of predominantly haematopoietic origin in either healthy or diseased individuals (Rogers et al, 1972; Lui et al, 2002). In cancer patients, a significant portion of the cfDNA presumably originates from the tumour. Many authors have identified common genetic (e.g., oncogenic mutations, microsatellite alterations) and epigenetic (e.g., tumour suppressor-gene promoter methylation) alterations in paired tumour tissue and plasma/serum samples (Fleischhacker and Schmidt, 2007). It has also been demonstrated that cfDNA is derived from apoptotic rather than necrotic processes under normal conditions (Stroun et al, 2000; Suzuki et al, 2008), whereas in cancer patients, it originates from both apoptotic and necrotic processes due to the high cellular turnover in the tumour (Stroun et al, 2001; Li et al, 2003). It should be stressed that the existing level of cfDNA in human blood is the effect of a dynamic balance between processes of cellular DNA release/secretion and mechanisms of DNA degradation and clearance. Thus, stability of distinct cfDNA forms in blood (Holdenrieder et al, 2010; Thakur et al, 2014), diminished activity of blood nucleases (Tamkovich et al, 2006), adsorption of cfDNA on blood cells (Tamkovich et al, 2008), as well as uptake and degradation of cfDNA by phagocytes (Choi et al, 2005) should also be considered as factors regulating the blood cfDNA levels in cancer patients.

Several studies have demonstrated significantly higher cfDNA concentrations in lung cancer patients compared with healthy individuals. However, considerable differences in methodological approach including sample processing and storage, plasma DNA extraction and quantification methods, and the choice of target genes has prevented the reliable comparisons necessary to determine the true clinical value of cfDNA quantification in lung cancer. Furthermore, certain clinical and pathological conditions that might affect cfDNA levels remain poorly defined for lung cancer groups. Consequently, it remains unclear if and to what extent the intense release of cfDNA into the bloodstream of lung cancer patients results from malignancy or chronic inflammatory response.

The aim of our study was to assess the effect of chronic respiratory inflammation on plasma cfDNA levels and evaluate the potential clinical value of this phenomenon as an early lung cancer diagnostic tool. Thus, apart from non-small-cell lung cancer (NSCLC) and healthy control groups, patients with chronic obstructive pulmonary disease (COPD), bronchial asthma, and pulmonary sarcoidosis were included to represent different instances of chronic respiratory inflammation.

\section{MATERIALS AND METHODS}

Study subjects. We recruited 50 consecutive NSCLC patients referred for lung surgery for this study. The NSCLC histologic subtypes were determined according to the World Health Organization classification as $22(44 \%)$ squamous cell carcinomas (SCCs), 24 (48\%) adenocarcinomas (ADCs), and four (8\%) other types. Postsurgical pathologic stage was defined according to the tumour node metastasis (TNM) International Staging System. There were 22 patients (44\%) with stage I, 20 (40\%) with stage II, and $8(16 \%)$ with stage IIIA NSCLC; no patients had received preoperative chemotherapy or radiotherapy.

Thirty-four patients with COPD, 35 patients with sarcoidosis, and 32 patients with bronchial asthma were included as model groups of respiratory diseases characterised by persistent inflammation. Chronic obstructive pulmonary disease was diagnosed, graded, and treated according to the 2009 GOLD guidelines (Global Initiative for Chronic Obstructive Lung Disease, 2010). Only patients with severe (GOLD 3) and very severe COPD (GOLD 4) were included. There were 19 (56\%) patients receiving inhaled corticosteroid therapy (low dose, six patients; moderate dose, eight patients; high dose, five patients).

Asthma was diagnosed according to the current GINA guidelines (Global Initiative for Asthma, 2010). Ten (31\%) patients presented with severe disease, nine $(28 \%)$ with moderate disease, seven $(22 \%)$ with mild disease, and six (19\%) with intermittent disease. In 24 patients (75\%), asthma was well controlled, and in 8 patients (25\%), asthma was uncontrolled. Eighteen of 32 (56\%) patients were persistently treated with inhaled corticosteroids, and two with systemic corticosteroids. Ten patients were included in the study before therapy initiation.

The diagnosis of sarcoidosis was established based on clinical and radiologic assessment supported by histological examination of lung biopsy specimens showing the presence of non-caseating granulomas. On the basis of radiological stratification, stage I pulmonary sarcoidosis was observed in 9 patients, stage II in 22 patients, and stage III in 4 patients. None of the patients had received systemic corticosteroid therapy for 6 weeks before blood collection. The healthy control group consisted of 40 volunteers.

The characteristics of patients and controls are presented in Table 1. The study was reviewed and approved by the local Ethics Committee. All patients gave their written informed consent.

Sample collection and plasma DNA extraction. Peripheral blood was collected once from every healthy volunteer and patient before treatment. Blood was collected in 9-ml tubes containing K3-EDTA and processed within $1 \mathrm{~h}$. Fresh blood samples were centrifuged at $1000 \mathrm{~g}$ for $10 \mathrm{~min}$ at $4{ }^{\circ} \mathrm{C}$. The supernatant was carefully transferred to a Falcon tube without disturbing the cellular layer and centrifuged again for $10 \mathrm{~min}$ for complete removal of any residual cells. Cell-free plasma was then aliquoted and stored at $80^{\circ} \mathrm{C}$ up to 3 months. DNA was extracted from a $0.5-\mathrm{ml}$ plasma aliquot with QIAmp DNA Blood Midi Kit (Qiagen, Hilden, Germany) according to the manufacturer's instructions and stored at $-20^{\circ} \mathrm{C}$ before further analysis.

Plasma DNA quantification by real-time PCR. Plasma DNA concentration was assessed by quantitative real-time PCR (QPCR) using human $\beta$-actin as a reference gene. The primer sequences were as follows: forward primer: $5^{\prime}$-GCACCACACCTTCTAC AATGA- $3^{\prime}$ and reverse primer: $5^{\prime}$-TGTCACGCACGATTTCCC- $3^{\prime}$ for a 100-bp amplicon. The standard curve was constructed by serial 10-fold dilutions of genomic DNA from pooled peripheral blood lymphocytes of five healthy donors. The concentration of genomic DNA standard was previously determined by UV absorbance measurements (NanoVue Plus Spectrophotometer, GE Healthcare UK Ltd., Buckinghamshire, UK). The dynamic range of the calibration curve was set at 0.01-100 ng DNA.

The QPCR was performed with a Chromo4 Multicolor Real-Time PCR Detection System (Bio-Rad Laboratories, Inc., Hercules, CA, USA), and each PCR reaction mixture consisted of $12.5 \mu \mathrm{l}$ master mix (FastStart Universal SYBR Green Master, Roche, Penzberg, Germany), $1.0 \mu \mathrm{l}$ each primer $(0.4 \mu \mathrm{M}), 2.5 \mu \mathrm{l}$ water, and $8 \mu \mathrm{l}$ of extracted DNA. The DNA was replaced by an equal volume of water in blank samples. The QPCR cycling conditions were as follows: polymerase activation at $95^{\circ} \mathrm{C}$ for $10 \mathrm{~min}$, followed by denaturation at $95^{\circ} \mathrm{C}$ for $20 \mathrm{~s}$, primer annealing, and elongation at $64{ }^{\circ} \mathrm{C}$ for $1 \mathrm{~min}$ and fluorescence read (excitation $\lambda=494 \mathrm{~nm}$, emission $\lambda=521 \mathrm{~nm}$ ); the sequence was repeated for 40 cycles. Melting curves were obtained from 55 to $90{ }^{\circ} \mathrm{C}$ with reads every $0.2^{\circ} \mathrm{C}$ for each amplicon.

Blank values were subtracted, and sample DNA concentration was extrapolated from the standard curve according to the Ct value 
Table 1. Study groups characteristics

\begin{tabular}{|c|c|c|c|}
\hline Characteristics & $N$ & & Percent (\%) \\
\hline \multicolumn{4}{|l|}{ NSCLC patients } \\
\hline$N$ & 50 & & 100 \\
\hline Median age (years), range & & 65 (39-84) & \\
\hline \multicolumn{4}{|l|}{ Sex } \\
\hline Male & 32 & & 64 \\
\hline Female & 18 & & 36 \\
\hline \multicolumn{4}{|l|}{ Histology (WHO) } \\
\hline $\mathrm{ADC}$ & 24 & & 48 \\
\hline SCC & 22 & & 44 \\
\hline Other & 4 & & 8 \\
\hline \multicolumn{4}{|l|}{ Stage (TNM) } \\
\hline 1 & 22 & & 44 \\
\hline ॥ & 20 & & 40 \\
\hline IIIA & 8 & & 16 \\
\hline \multicolumn{4}{|l|}{ COPD patients } \\
\hline$N$ & 34 & & 100 \\
\hline Median age (years), range & & $69(41-82)$ & \\
\hline \multicolumn{4}{|l|}{ Sex } \\
\hline Male & 23 & & 67.6 \\
\hline Female & 11 & & 32.4 \\
\hline \multicolumn{4}{|l|}{ Asthma patients } \\
\hline$N$ & 32 & & 100 \\
\hline Median age (years), range & & $55(23-80)$ & \\
\hline \multicolumn{4}{|l|}{ Sex } \\
\hline Male & 13 & & 40.6 \\
\hline Female & 19 & & 59.4 \\
\hline \multicolumn{4}{|l|}{ Sarcoidosis patients } \\
\hline$N$ & 35 & & 100 \\
\hline Median age (years), range & & $44(29-65)$ & \\
\hline \multicolumn{4}{|l|}{ Sex } \\
\hline Male & 19 & & 54.3 \\
\hline Female & 16 & & 45.7 \\
\hline \multicolumn{4}{|l|}{ Healthy controls } \\
\hline$N$ & 40 & & 100 \\
\hline Median age (years), range & & $40.5(24-66)$ & \\
\hline \multicolumn{4}{|l|}{ Sex } \\
\hline Male & 13 & & 32.5 \\
\hline Female & 27 & & 67.5 \\
\hline \multicolumn{4}{|c|}{$\begin{array}{l}\text { Abbreviations: } \mathrm{ADC}=\text { adenocarcinoma; } \mathrm{COPD}=\text { chronic obstructive pulmonary disease; } \\
\text { NSCLC = non-small-cell lung cancer; } \mathrm{SCC}=\text { squamous cell carcinoma; } \mathrm{TNM}=\text { tumour node } \\
\text { metastasis. }\end{array}$} \\
\hline
\end{tabular}

by the MJ Opticon Monitor 3.1 software (Bio-Rad Laboratories, Inc.). All samples were processed in duplicate.

Statistical analysis. Plasma DNA concentration values are expressed as means \pm s.d. The basic descriptive statistics for all groups are summarised in Table 2 to allow meaningful comparisons with other reports. The variability of result sets was calculated as s.d., variance and coefficient of variation $(\mathrm{CV})$. The normality of the data was assessed by the Shapiro-Wilk test. The nonoparametric Kruskal-Wallis one-way analysis of variance by ranks was used for comparison of means.

The receiver operator characteristics (ROC) curve was constructed to evaluate the diagnostic capability of plasma DNA concentration to discriminate cases from controls. Each plasma DNA concentration value was used as a cutoff to calculate the sensitivity and specificity, thus defining the area under the curve (AUC). A $P$-value of $<0.05$ was considered statistically significant.
Table 2. Basic statistics of plasma DNA quantification results (ng DNA per $\mathrm{ml}$ plasma)

\begin{tabular}{|l|c|c|c|c|c|c|l|}
\hline Group & $\mathbf{N}$ & Mean & s.d. & Median & Range & Variance & s.e. \\
\hline NSCLC & 50 & 8.02 & 7.81 & 5.87 & $1.12-40.98$ & 61.05 & 1.10 \\
\hline COPD & 34 & 3.97 & 2.03 & 3.80 & $1.11-10.17$ & 4.11 & 0.37 \\
\hline Sarcoidosis & 35 & 3.68 & 2.07 & 3.30 & $1.00-10.91$ & 4.28 & 0.35 \\
\hline Asthma & 32 & 3.02 & 2.19 & 2.45 & $0.51-8.96$ & 4.81 & 0.41 \\
\hline Healthy & 40 & 2.27 & 1.51 & 1.87 & $0.72-6.49$ & 2.28 & 0.24 \\
\hline
\end{tabular}

\section{RESULTS}

Real-time PCR assay performance. Plasma DNA concentration was measured by real-time PCR using the $\beta$-actin gene as the amplifying target. The plasma DNA amplified efficiently in all samples tested, and the calculated concentration values were $0.51-40.98 \mathrm{ng} \mathrm{ml}^{-1}$. The QPCR assay performance demonstrated very high linearity of product amplification assessed as the mean slope $(m=-3.20)$ and the mean correlation coefficient $\left(R^{2}=0.99\right)$ of all standard curves constructed. Similarly, a low s.d. (0.17) and CV of the threshold cycles values (0.84\%) for all standard curves confirmed satisfactory precision and reproducibility. The average QPCR efficiency was $97 \%$, and the mean CV of the threshold cycles was $0.44 \%$ for all samples tested. None of the blank samples amplified.

The specificity of QPCR amplification products was verified by melting curve analysis. All plasma DNA samples demonstrated a single peak corresponding to $84^{\circ} \mathrm{C}$ in their melting curves. This confirmed the high specificity of the selected primers and the absence of nonspecific amplification products in QPCR assays.

Plasma DNA concentration in patients and controls. The plasma DNA assessed by real-time PCR presented the highest concentration in NSCLC patients with a mean of $8.02 \pm 7.81 \mathrm{ng} \mathrm{ml}^{-1}$, whereas the lowest concentration was found in healthy volunteers, with a mean of $2.27 \pm 1.51 \mathrm{ng} \mathrm{ml}^{-1}$. Patients with chronic respiratory inflammation presented intermediate plasma DNA levels, with a mean of $3.36 \pm 1.80 \mathrm{ng} \mathrm{ml}^{-1}$; this included $3.97 \pm 2.03 \mathrm{ng} \mathrm{ml}^{-1}$ in the COPD group, $3.68 \pm 2.07 \mathrm{ngml}^{-1}$ in the sarcoidosis group, and $3.02 \pm 2.19 \mathrm{ng} \mathrm{ml}^{-1}$ in asthma patients. The median values of plasma DNA concentration were slightly different from the means in all groups, and s.d. and variance were remarkably higher in the NSCLC group (Table 2).

Shapiro-Wilk analysis confirmed significant deviations from a normal distribution $(P<0.0163)$ in all groups; therefore, the quantitative results were further compared using Kruskal-Wallis non-parametric ANOVA. The NSCLC patients demonstrated significantly higher mean plasma DNA concentration than patients with chronic respiratory inflammation and healthy volunteers $(P<0.0001$, Figure 1). Interestingly, there were no significant differences in plasma DNA levels between patients with chronic respiratory inflammation and healthy volunteers. When considered separately, only COPD patients, but not sarcoidosis or asthma patients, presented statistically different cfDNA concentrations from healthy controls $(P=0.0381)$. Similarly, the mean plasma DNA level in the NSCLC group was significantly higher than that in patients with sarcoidosis $(P=0.0132)$ and asthma $(P<0.0001)$, but not COPD $(P=0.0974)$ groups.

On the basis of the observed variation in plasma DNA concentration within the NSCLC group, data were analysed according to tumour histology and disease stage. However, no significant differences were found.

Diagnostic power of plasma DNA quantification. To evaluate the discriminative power of the cfDNA concentration, ROC curve analysis was performed. The test demonstrated significant accuracy 
in distinguishing NSCLC patients from healthy individuals. The calculated ROC AUC was 0.90 (95\% CI, 0.81-0.95), which was suggestive of a high discrimination power $(P<0.0001)$. The highest accuracy was obtained at a cutoff point of $>2.80 \mathrm{ng} \mathrm{ml}^{-1}$, which corresponded to sensitivity and specificity of $90 \%$ and $80.5 \%$, respectively. Satisfactory positive predictive value (PPV) of $85 \%$ and negative predictive value (NPV) of $87 \%$ were also demonstrated (Figure 2).

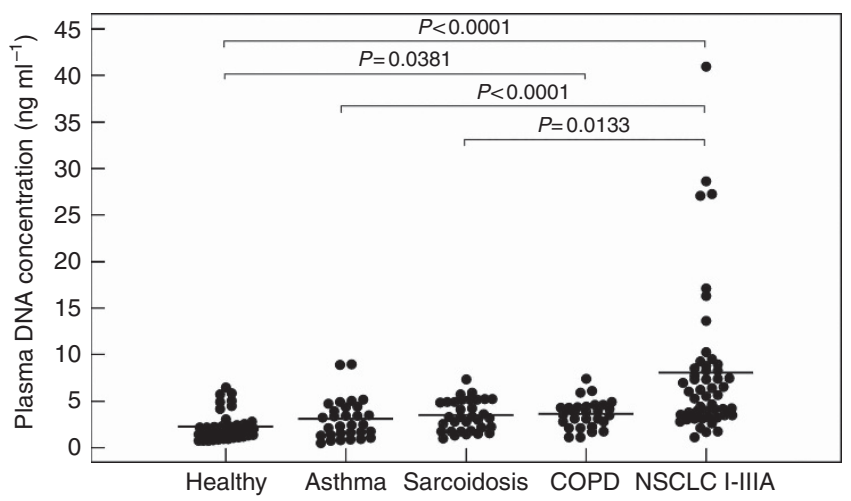

Figure 1. Distribution of cfDNA levels in the plasma of patients with resectable NSCLC, chronic respiratory inflammatory disorders (asthma, sarcoidosis, COPD) and healthy individuals (bars represent means). The Kruskal-Wallis one-way analysis of variance by ranks was performed to test differences in plasma cfDNA levels between groups.

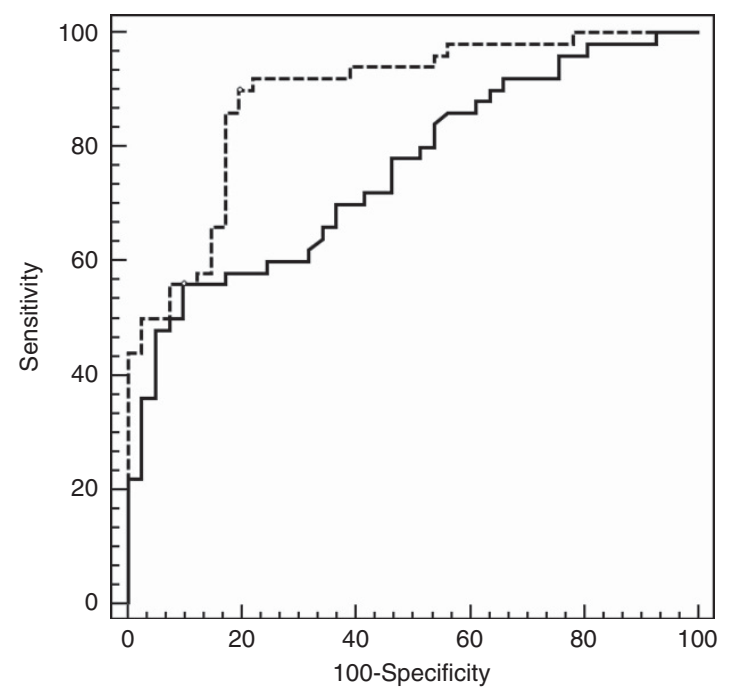

Figure 2. Receiver-operating characteristics plots from comparison of normal subjects vs NSCLC group (dashed line) and chronic respiratory inflammation patients vs NSCLC group (solid line).
Importantly, the diagnostic power of the cfDNA concentration to discriminate NSCLC patients from subjects with chronic respiratory inflammation was also demonstrated. At the optimal cutoff point of $>5.25 \mathrm{ng} \mathrm{ml}^{-1}$, test sensitivity was $56 \%$ and the specificity, $91 \%$. Lower cutoff values increased the sensitivity of the assay, but at the cost of specificity, and vice versa (Table 3 ). The ROC AUC was 0.76 (95\% CI, 0.68-0.83; $P<0.0001)$, and PPV and NPV were $77.8 \%$ and $78.6 \%$, respectively (Figure 2 ). The two ROC curves differed significantly $(P=0.0044)$.

The diagnostic power of cfDNA concentration did not change markedly when healthy individuals were grouped with chronic respiratory inflammation patients (56\% sensitivity, $90 \%$ specificity; 66.7\% PPV, 84.5\% NPV for the cutoff point of $>5.25 \mathrm{ng} \mathrm{ml}^{-1}$; $\mathrm{AUC}=0.79 ; 95 \% \mathrm{CI}, 0.73-0.85, P<0.0001)$. The s.e. was relatively low for all ROC measurements (s.e. $<0.05)$.

\section{DISCUSSION}

The plasma cfDNA phenomenon in lung cancer patients has been studied extensively in recent years. The intense vascularisation of lung parenchyma suggests a close relationship between lung cells and the circulation. Thus, we strongly believe that both the cfDNA concentration and its molecular characteristics may be exploited for future diagnostic applications. Several studies have reported higher levels of cfDNA in the plasma or serum of lung cancer patients compared with that of healthy donors, albeit with different levels obtained with different methodologies (ChorostowskaWynimko and Szpechcinski, 2007; Ulivi and Silvestrini, 2013). However, there are few data describing this phenomenon in other respiratory disorders, particularly those related to chronic inflammation. Accordingly, the present study assessed the effect of chronic respiratory inflammation on plasma cfDNA levels and evaluated the potential clinical value of this phenomenon as an early lung cancer diagnostic tool. The plasma DNA concentration was assessed in resectable NSCLC groups (stages I-IIIA) and compared with healthy controls and with patients with COPD, bronchial asthma, and pulmonary sarcoidosis, representing distinctive causes of chronic lung inflammation with preferential recruitment of Th1 lymphocytes, Th2 lymphocytes, or macrophages.

To ensure high-quality DNA quantification we used real-time PCR with SYBR Green I detection, which provides excellent precision, repeatability, and concordance with other fluorescence assays for total and amplifiable DNA quantification (Szpechcinski et al, 2008). Similarly, we decided to use plasma but not the serum samples for cfDNA quantification, as plasma isolated from EDTA-treated blood has been shown repeatedly to be more suitable for this application (Jung et al, 2003; Taback et al, 2004; Park et al, 2012).

The demographic characteristics of the patients and control groups in this study differed slightly. However, this did not affect reliability of the statistical analysis or final conclusions. In fact, the

Table 3. Test performance characteristics with respect to the different threshold values

\begin{tabular}{|c|c|c|c|c|c|c|c|}
\hline Groups & cfDNA level (ng ml ${ }^{-1}$ ) & Sensitivity \% & $95 \% \mathrm{Cl}$ & Specificity \% & $95 \% \mathrm{Cl}$ & $+\mathrm{PV} \%$ & $-\mathrm{PV} \%$ \\
\hline \multirow[t]{3}{*}{ NSCLC vs normal } & $>1.11$ & 100.0 & $92.9-100$ & 21.9 & $10.6-37.6$ & 61.0 & 100 \\
\hline & $>2.80^{a}$ & 90.0 & $78.2-96.7$ & 80.5 & $65.1-91.2$ & 84.9 & 86.8 \\
\hline & $>5.68$ & 50.0 & $35.5-64.5$ & 92.7 & $80.1-98.5$ & 89.3 & 60.3 \\
\hline \multirow[t]{3}{*}{ NSCLC vs chronic respiratory inflammation } & $>1.11$ & 100.0 & $92.9-100.0$ & 7.9 & $3.2-15.5$ & 37.9 & 100.0 \\
\hline & $>2.81$ & 88.0 & $75.7-95.5$ & 40.4 & $30.2-51.4$ & 45.4 & 85.7 \\
\hline & $>5.25^{\mathrm{a}}$ & 56.0 & $41.3-70.0$ & 91.0 & $83.1-96.0$ & 77.8 & 78.6 \\
\hline
\end{tabular}


potential impact of age and gender on the regulation of plasma DNA levels has not been consistently demonstrated or properly addressed in the literature. Tamkovich et al (2005) did not observe any significant gender-related differences in plasma DNA from healthy females ( $15 \mathrm{ng} \mathrm{ml}^{-1}, n=20$, age $25-53$ years) and males (16 $\mathrm{ng} \mathrm{ml}^{-1}, n=15$, age 18-43 years). A study by Jylhävä et al (2011) was the only study to report significant age-related differences, with higher plasma DNA levels in elderly women $(n=12,>90$ years of age) relatively to the younger controls $(n=11,22-37$ years of age; $P<0.05$ ). However, the reliability of both data sets remains uncertain owing to the small sample size and imbalanced groups. There are similar concerns related to control subjects. Data obtained in healthy individuals from the two largest case-control studies in lung cancer were contradictory. Sozzi et al (2003) demonstrated a significant positive relationship between age and plasma DNA concentration in 100 NSCLC patients and an equal number of healthy controls matched by gender and age (mean age of 65.1 and 64.1 years, respectively; $P=0.001$ ). However, Yoon et al (2009) observed no significant association between plasma DNA concentration and age or gender in a group of 102 patients and 105 matched controls. Therefore, any comprehensive analysis of this issue will need to be specifically addressed in a case-control matched study with considerably larger cohorts $(n>100)$.

In our study, NSCLC patients had significantly higher mean plasma DNA concentrations compared with healthy controls (8.02 vs $2.27 \mathrm{ng} \mathrm{ml}^{-1}$, respectively; $P<0.0001$ ). Plasma DNA levels were not significantly related to the NSCLC stage (I-IIIA) or histology (ADC or SCC; $P>0.05$ ). Several groups have evaluated plasma DNA levels in resectable NSCLC patients. Sozzi et al (2001) used a simple colorimetric assay to report up to 17-fold higher levels of plasma DNA in 84 NSCLC patients compared with 43 healthy controls (318 vs $\left.18 \mathrm{ng} \mathrm{ml}^{-1} ; P<0.05\right)$. No correlation between plasma DNA level and stage or NSCLC histology was observed. Importantly, the NSCLC group in their study was similar to ours in terms of number, age (mean 63 years), gender $(14 \%$ women, $86 \%$ men), lung cancer histology (56\% ADC, 30\% SCC, and $14 \%$ other), and staging (55\% stage I, $18 \%$ II, and $27 \%$ III). Similarly, Paci et al (2009) reported an approximately four-fold higher concentration of circulating human telomerase reverse transcriptase DNA measured by QPCR in a group of 151 patients with lung cancer compared with 79 healthy controls (12.8 vs $2.9 \mathrm{ng} \mathrm{ml}^{-1}, P<0.001$; Table 4). Ludovini et al (2008) demonstrated significantly higher plasma DNA levels in 76 lung cancer patients (mean $60.0 \pm 99.8 \mathrm{ng} \mathrm{ml}^{-1}$ ) compared with 66 controls (mean $6.0 \pm 8.8 \mathrm{ng} \mathrm{ml}^{-1}, P<0.0001$ ). Neither Ludovini et al nor Paci et al noted any significant differences in plasma DNA levels according to the NSCLC stage and histology. Still, the differences in plasma DNA concentration per se reported by respective authors are striking. As mentioned earlier, the diversity of cfDNA extraction and quantification methods applied by different groups preclude any reliable comparisons. However, the considerable overlap in concentration ranges between lung cancer patients and controls, as well as noticeably higher s.d. values in cancer observed in most studies assessing the plasma DNA, certainly reflect the biological complexity and diversity of tumour-host interactions.

In our study, the stage I-IIIA NSCLC group was characterised by significantly higher mean plasma DNA level than were patients with chronic respiratory inflammation $(P<0.0001)$. The latter presented a two-fold increase in cfDNA concentration compared with healthy controls, although this difference was not statistically significant $(P<0.05)$. Interestingly, the mean and median cfDNA levels in COPD patients were the highest in the chronic respiratory inflammation group, albeit still two-fold lower than the mean and median values presented by NSCLC $(P>0.05)$. This observation is consistent with data reported by Van der Drift et al (2010), who found no significant differences in plasma cfDNA levels in 46 NSCLC patients with or without concomitant COPD. In their study, however, NSCLC patients presented with mostly mild (24\%) or moderate (61\%) COPD, whereas we investigated COPD patients with severe and very severe disease characterised by increased inflammatory processes and more severe lung destruction.

Chronic oxidative stress and persistent local inflammation have been implicated in the pathogenesis of both lung cancer and a number of non-malignant respiratory disorders, including COPD, asthma, and pulmonary sarcoidosis. Interestingly, cfDNA in idiopathic pulmonary fibrosis (IPF) seems to present a distinctive pattern more similar to lung cancer than chronic inflammatory disorders. Casoni et al (2010) demonstrated that the cfDNA serum level in 58 IPF patients (median $61.1 \mathrm{ng} \mathrm{ml}^{-1}$ ) was two-fold higher than that in 52 patients with other inflammatory non-malignant respiratory diseases (median $28.0 \mathrm{ng} \mathrm{ml}^{-1}, P=0.004$ ) and ninefold higher than that in 64 healthy donors (median $6.8 \mathrm{ng} \mathrm{ml}^{-1}$, $P<0.001)$. Unfortunately, their choice to use serum as the cfDNA source precludes any direct comparison with our data, though the cfDNA quantification methods were similar.

To evaluate the diagnostic power of the quantitative cfDNA assay to discriminate NSCLC from non-malignant inflammatory diseases and healthy individuals, ROC curve analysis was performed. The cutoff value of $2.8 \mathrm{ng} \mathrm{ml}^{-1}$ provided $90 \%$ sensitivity and $80.5 \%$ specificity in discriminating resectable NSCLC from healthy individuals $(\mathrm{AUC}=0.90$, PPV 85\%, NPV $87 \%$ ). This discriminative value is similar to reports from other groups (Table 4). Even though Roz et al (2009) observed even higher discriminatory power of cfDNA for stage I-II $(\mathrm{AUC}=1)$ than stage for III NSCLC patients $(\mathrm{AUC}=0.80)$, VAN Boerdonk et al (2013) found no significant rise in plasma cfDNA in the preinvasive stages of lung squamous carcinogenesis defined in this study of AFB-visualised (autofluorescence bronchoscopy) preinvasive endobronchial lesions compared with healthy controls.

The direct comparison of the plasma cfDNA discriminative value for NSCLC and healthy subjects suggests that its quantification might be of clinical value as an auxiliary tool for lung cancer screening. Moreover, the assessment of cfDNA diagnostic utility performed within this study closely mimics clinical practice. The cfDNA discriminative value in NSCLC was evaluated in comparison to subjects with chronic inflammatory lung disorders. The ROC curve analysis presented noticeably lower discriminatory power, and the cutoff was established at $5.25 \mathrm{ng} \mathrm{ml}^{-1}$ with $56 \%$ sensitivity and $91 \%$ specificity (AUC $=0.76$, PPV 77.8\%, NPV 78.6\%, $P<0.0001$ ).

The use of plasma cfDNA quantification as a diagnostic marker for cancer detection has been questioned by Schmidt et al (2008), who found no significant differences in plasma and serum cfDNA levels between 33 lung cancer patients (21 NSCLC, 8 SCLC, 1 cholangiocarcinoma with lung metastases, 1 oropharyngeal cancer with lung metastases, and 2 lung cancer of unknown histology) and 27 patients with a benign lung disease ( 5 bronchitis, 6 fibrosis, 16 other benign lung diseases including COPD, benign stenosis, granuloma, pneumonia, and scleroderma). Their study, however, differed from ours in terms of the method of cfDNA isolation and quantification, as well as in the characteristics and numbers of patient populations. The use of a mixed population of either NSCLC or SCLC patients without detailed data on their clinical and pathological status (stage, histology) together with lack of a healthy control group reference abates the power of negative conclusions coming from this study.

Importantly, the diagnostic power of the quantitative cfDNA assay presented in our study, exceeds many other serological markers used in lung cancer, for example, CYFRA21-1, CEA, CA125, CA153, CA19-9, NSE, SSC-Ag, and TIMP-1 (AUC values: $0.90,0.591,0.621,0.571,0.459,0.74,0.71$, and 0.519 , respectively) (Vassilakopoulos et al, 2001; Kulpa et al, 2002; Suemitsu et al, 2004; Zhang et al, 2009). Interestingly, the discriminative power of quantitative cfDNA assessment for NSCLC improves considerably when combined with other existing 


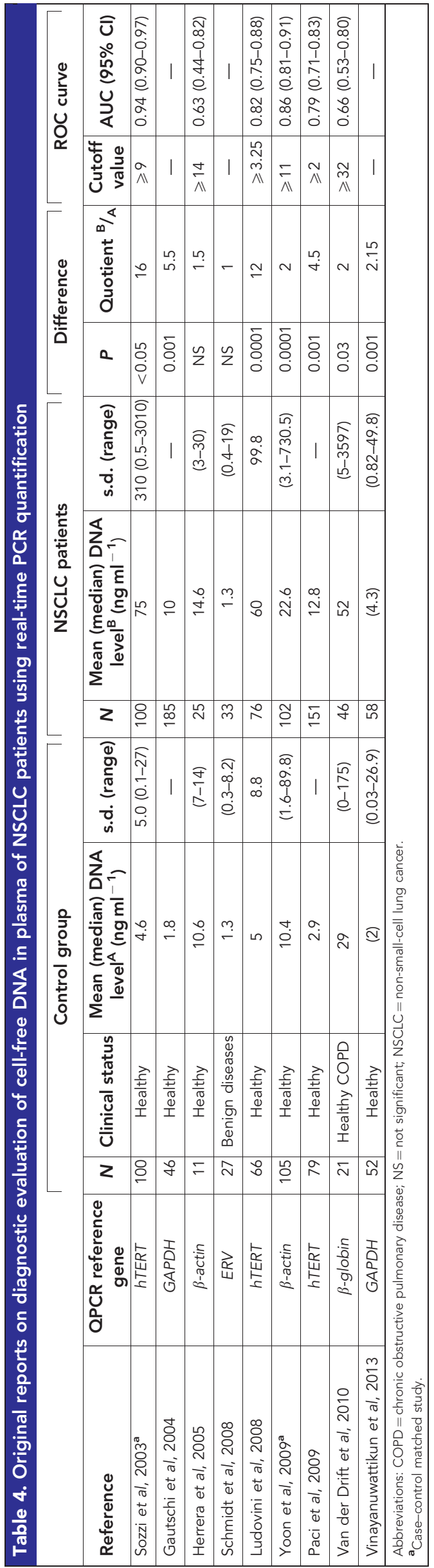

tumour markers, such as CEA (Maebo, 1990), CYFRA21-1, NSE, SSC-Ag (Wu et al, 2013), or assessment of tumour-related molecular alterations (microsatellite alterations, tumour suppressorgene methylation; Bearzatto et al, 2002). As most authors focus their current efforts on a single qualitative marker assessment in plasma cfDNA from NSCLC patients, for example, EGFR and KRAS mutations, tumour suppressor-gene methylation or microsatellite alterations, comprehensive studies evaluating multiple, quantitative and qualitative cfDNA markers for lung cancer screening and early detection are lacking. A similar, multi-marker approach has been recently proven effective in non-invasive colorectal cancer diagnosis, showing great promise for implementation of personalised medicine for this disease (Mouliere et al, 2014).

Some contemporary studies are now looking specifically at circulating tumour DNA (ctDNA) as a NSCLC biomarker rather than total cfDNA quantity. In many tumour types, ctDNA comprises only a small fraction of the total blood cfDNA (0.01-10\%) (Diehl et al, 2005, 2008; Diaz and Bardelli, 2014), although values of $\sim 90 \%$ have also been reported (Jahr et al, 2001). However, the quantification of the circulating tumour DNA levels in cancer patients may not reflect the actual content of ctDNA in the total fraction when only single tumour marker (e.g., gene mutation, methylation) is assessed. Absolute and relative ctDNA concentrations, as well as the prevalence of cancer patients who have detectable levels of ctDNA in their blood, are all strongly correlated to cancer type (Bettegowda et al, 2014) and clinicopathological features such as tumour stage (Diehl et al, 2005; Bettegowda et al, 2014). Probably, the aggressive growth of tumour and its ability to invade and spread also contributes to the concentration levels of both cfDNA and ctDNA by exacerbating processes responsible for its release into the bloodstream, such as chronic inflammation. Therefore, the amount of cell-free DNA may vary significantly among individuals with different clinical histories of malignant disease. This explains our data showing higher levels of cell-free DNA in lung cancer patients though most of their plasma DNA is actually considered to originate from normal cells.

In summary, we demonstrated significantly higher plasma cfDNA levels in NSCLC patients than in individuals with chronic respiratory inflammation and healthy controls. Despite the pathological mechanism of chronic respiratory inflammation, as represented by COPD, asthma, and sarcoidosis, the plasma cfDNA level was below the values noted in NSCLC. Our results strongly suggest that elevated plasma cfDNA levels in NSCLC patients result primarily from tumour development, raising the potential clinical implications for lung cancer screening and early diagnosis. As most authors reporting on plasma cfDNA quantification evaluated NSCLC patients with respect to healthy controls only, the actual diagnostic utility of plasma cfDNA concentration measurement has never been validated thoroughly. In our study, ROC curve analysis revealed that while plasma cfDNA quantification results in a high diagnostic capacity to discriminate between NSCLC and healthy individuals, assay sensitivity, and PPV decrease when patients with chronic respiratory inflammation are included into the evaluation. Further research is necessary for better cfDNA characterisation and identification of factors and processes regulating its level in blood under normal and pathological conditions before speculation on its diagnostic use.

\section{ACKNOWLEDGEMENTS}

This study was supported by the research grant from The Count Jakub Potocki Foundation, Poland. We thank the patients who participated in the study. The English in this document has been checked by at least two professional editors, both native speakers of 
English. For a certificate, please see http://www.textcheck.com/ certificate/rKI8OT.

\section{CONFLICT OF INTEREST}

The authors declare no conflict of interest.

\section{REFERENCES}

Bearzatto A, Conte D, Frattini M, Zaffaroni N, Andriani F, Balestra D, Tavecchio L, Daidone MG, Sozzi G (2002) p16(INK4A) Hypermethylation detected by fluorescent methylation-specific PCR in plasmas from non-small cell lung cancer. Clin Cancer Res 8: 3782-3787.

Bettegowda C, Sausen M, Leary RJ, Kinde I, Wang Y, Agrawal N, Bartlett BR, Wang H, Luber B, Alani RM, Antonarakis ES, Azad NS, Bardelli A, Brem H, Cameron JL, Lee CC, Fecher LA, Gallia GL, Gibbs P, Le D, Giuntoli RL, Goggins M, Hogarty MD, Holdhoff M, Hong SM, Jiao Y, Juhl HH, Kim JJ, Siravegna G, Laheru DA, Lauricella C, Lim M, Lipson EJ, Marie SK, Netto GJ, Oliner KS, Olivi A, Olsson L, Riggins GJ, Sartore-Bianchi A, Schmidt K, Shih IM, Oba-Shinjo SM, Siena S, Theodorescu D, Tie J, Harkins TT, Veronese S, Wang TL, Weingart JD, Wolfgang CL, Wood LD, Xing D, Hruban RH, Wu J, Allen PJ, Schmidt CM, Choti MA, Velculescu VE, Kinzler KW, Vogelstein B, Papadopoulos N, Diaz Jr LA (2014) Detection of circulating tumor DNA in early- and late-stage human malignancies. Sci Transl Med 6: 224ra24.

Casoni GL, Ulivi P, Mercatali L, Chilosi M, Tomassetti S, Romagnoli M, Ravaglia C, Gurioli C, Gurioli C, Zoli W, Silvestrini R, Poletti V (2010) Increased levels of free circulating DNA in patients with idiopathic pulmonary fibrosis. Int J Biol Markers 25: 229-235.

Choi JJ, Reich 3rd CF, Pisetsky DS (2005) The role of macrophages in the in vitro generation of extracellular DNA from apoptotic and necrotic cells. Immunology 115: 55-62.

Chorostowska-Wynimko J, Szpechcinski A (2007) The impact of genetic markers on the diagnosis of lung cancer: a current perspective. $J$ Thorac Oncol 2: 1044-1051.

Diaz Jr LA, Bardelli A (2014) Liquid biopsies: genotyping circulating tumor DNA. J Clin Oncol 32: 579-586.

Diehl F, Li M, Dressman D, He Y, Shen D, Szabo S, Diaz Jr LA, Goodman SN, David KA, Juhl H, Kinzler KW, Vogelstein B (2005) Detection and quantification of mutations in the plasma of patients with colorectal tumors. Proc Natl Acad Sci USA 102: 16368-16373.

Diehl F, Schmidt K, Choti MA, Romans K, Goodman S, Li M, Thornton K, Agrawal N, Sokoll L, Szabo SA, Kinzler KW, Vogelstein B, Diaz Jr LA (2008) Circulating mutant DNA to assess tumor dynamics. Nat Med 14: 985-990.

Fleischhacker M, Schmidt B (2007) Circulating nucleic acids (CNAs) and cancer-a survey. Biochim Biophys Acta 1775: 181-232.

Gautschi O, Bigosch C, Huegli B, Jermann M, Marx A, Chassé E, Ratschiller D, Weder W, Joerger M, Betticher DC, Stahel RA, Ziegler A (2004) Circulating deoxyribonucleic acid as prognostic marker in non-small-cell lung cancer patients undergoing chemotherapy. $J$ Clin Oncol 22: 4157-4164.

Global Initiative for Asthma (2010) GINA; Global strategy for asthma management and prevention (update) http://www.ginasthma.org/ guidelines-gina-report-global-strategy-for-asthma.html (Accessed December 2011).

Global Initiative for Chronic Obstructive Lung Disease (2010) GOLD; Global strategy for diagnosis, management, and prevention of COPD (update) http://www.goldcopd.org/guidelines-global-strategy-for-diagnosismanagement.html (Accessed December 2011).

Herrera LJ, Raja S, Gooding WE, El-Hefnawy T, Kelly L, Luketich JD, Godfrey TE (2005) Quantitative analysis of circulating plasma DNA as a tumor marker in thoracic malignancies. Clin Chem 51: 113-118.

Holdenrieder S, Von Pawel J, Nagel D, Stieber P (2010) Long-term stability of circulating nucleosomes in serum. Anticancer Res 30: 1613-1615.

Jahr S, Hentze H, Englisch S, Hardt D, Fackelmayer FO, Hesch RD, Knippers R (2001) DNA fragments in the blood plasma of cancer patients: quantitations and evidence for their origin from apoptotic and necrotic cells. Cancer Res 61: 1659-1665.
Jung M, Klotzek S, Lewandowski M, Fleischhacker M, Jung K (2003) Changes in concentration of DNA in serum and plasma during storage of blood samples. Clin Chem 49: 1028-1029.

Jylhävä J, Kotipelto T, Raitala A, Jylhä M, Hervonen A, Hurme M (2011) Aging is associated with quantitative and qualitative changes in circulating cell-free DNA: the Vitality $90+$ study. Mech Ageing Dev 132: 20-26.

Kulpa J, Wójcik E, Reinfuss M, Kołodziejski L (2002) Carcinoembryonic antigen, squamous cell carcinoma antigen, CYFRA 21-1, and neuronspecific enolase in squamous cell lung cancer patients. Clin Chem 48: 1931-1937.

Li CN, Hsu HL, Wu TL, Tsao KC, Sun CF, Wu JT (2003) Cell-free DNA is released from tumor cells upon cell death: a study of tissue cultures of tumor cell lines. J Clin Lab Anal 17: 103-107.

Ludovini V, Pistola L, Gregorc V, Floriani I, Rulli E, Piattoni S, Di Carlo L, Semeraro A, Darwish S, Tofanetti FR, Stocchi L, Mihaylova Z, Bellezza G, Del Sordo R, Daddi G, Crinò L, Tonato M (2008) Plasma DNA, microsatellite alterations, and p53 tumor mutations are associated with disease-free survival in radically resected non-small cell lung cancer patients: a study of the Perugia multidisciplinary team for thoracic oncology. J Thorac Oncol 3: 365-373.

Lui YY, Chik KW, Chiu RW, Ho CY, Lam CW, Lo YM (2002) Predominant hematopoietic origin of cell-free DNA in plasma and serum after sex-mismatched bone marrow transplantation. Clin Chem 48: 421-427.

Maebo A (1990) Plasma DNA level as a tumor marker in primary lung cancer. Nihon Kyobu Shikkan Gakkai Zasshi 28: 1085-1091.

Mouliere F, El Messaoudi S, Pang D, Dritschilo A, Thierry AR (2014) Multi-marker analysis of circulating cell-free DNA toward personalized medicine for colorectal cancer. Mol Oncol 8: 927-941.

Paci M, Maramotti S, Bellesia E, Formisano D, Albertazzi L, Ricchetti T, Ferrari G, Annessi V, Lasagni D, Carbonelli C, De Franco S, Brini M, Sgarbi G, Lodi R (2009) Circulating plasma DNA as diagnostic biomarker in non-small cell lung cancer. Lung Cancer 64: 92-97.

Park JL, Kim HJ, Choi BY, Lee HC, Jang HR, Song KS, Noh SM, Kim SY, Han DS, Kim YS (2012) Quantitative analysis of cell-free DNA in the plasma of gastric cancer patients. Oncol Lett 3: 921-926.

Rogers JC, Boldt D, Kornfeld S, Skinner A, Valeri CR (1972) Excretion of deoxyribonucleic acid by lymphocytes stimulated with phytohaemagglutinin or antigen. Proc Natl Acad Sci USA 69: 1685-1689.

Roz L, Verri C, Conte D, Miceli R, Mariani L, Calabro' E, Andriani F, Pastorino U, Sozzi G (2009) Plasma DNA levels in spiral CT-detected and clinically detected lung cancer patients: a validation analysis. Lung Cancer 66: $270-271$.

Schmidt B, Weickmann S, Witt C, Fleischhacker M (2008) Integrity of cell-free plasma DNA in patients with lung cancer and nonmalignant lung disease. Ann NY Acad Sci 1137: 207-213.

Siegel R, Naishadham D, Jemal A (2012) Cancer statistics, 2012. CA Cancer J Clin 62: 10-29.

Sozzi G, Conte D, Leon M, Ciricione R, Roz L, Ratcliffe C, Roz E, Cirenei N, Bellomi M, Pelosi G, Pierotti MA, Pastorino U (2003) Quantification of free circulating DNA as a diagnostic marker in lung cancer. J Clin Oncol 21: 3902-3908.

Sozzi G, Conte D, Mariani L, Lo Vullo S, Roz L, Lombardo C, Pierotti MA, Tavecchio L (2001) Analysis of circulating tumor DNA in plasma at diagnosis and during follow-up of lung cancer patients. Cancer Res 61: 4675-4678.

Stroun M, Lyautey J, Lederrey C, Olson-Sand A, Anker P (2001) About the possible origin and mechanism of circulating DNA apoptosis and active DNA release. Clin Chim Acta 313: 139-142.

Stroun M, Maurice P, Vasioukhin V, Lyautey J, Lederrey C, Lefort F, Rossier A, Chen XQ, Anker P (2000) The origin and mechanism of circulating DNA. Ann NY Acad Sci 906: 161-168.

Suemitsu R, Yoshino I, Tomiyasu M, Fukuyama S, Okamoto T, Maehara Y (2004) Serum tissue inhibitors of metalloproteinase-1 and -2 in patients with non-small cell lung cancer. Surg Today 34: 896-901.

Suzuki N, Kamataki A, Yamaki J, Homma Y (2008) Characterization of circulating DNA in healthy human plasma. Clin Chim Acta 387: $55-58$.

Szpechcinski A, Struniawski R, Zaleska J, Chabowski M, Orlowski T, Roszkowski K, Chorostowska-Wynimko J (2008) Evaluation of fluorescence-based methods for total vs. amplifiable DNA quantification in plasma of lung cancer patients. J Physiol Pharmacol 59: 675-681.

Taback B, O'Day SJ, Hoon DS (2004) Quantification of circulating DNA in the plasma and serum of cancer patients. Ann NY Acad Sci 1022: 17-24. 
Tamkovich SN, Bryzgunova OE, Rykova EY, Permyakova VI, Vlassov VV, Laktionov PP (2005) Circulating nucleic acids in blood of healthy male and female donors. Clin Chem 51: 1317-1319.

Tamkovich SN, Cherepanova AV, Kolesnikova EV, Rykova EY, Pyshnyi DV, Vlassov VV, Laktionov PP (2006) Circulating DNA and DNase activity in human blood. Ann NY Acad Sci 1075: 191-196.

Tamkovich SN, Litviakov NV, Bryzgunova OE, Dobrodeev AY, Rykova EY, Tuzikov SA, Zav'ialov AA, Vlassov VV, Cherdyntseva NV, Laktionov PP (2008) Cell-surface-bound circulating DNA as a prognostic factor in lung cancer. Ann NY Acad Sci 1137: 214-217.

Thakur BK, Zhang H, Becker A, Matei I, Huang Y, Costa-Silva B, Zheng Y, Hoshino A, Brazier H, Xiang J, Williams C, Rodriguez-Barrueco R, Silva JM, Zhang W, Hearn S, Elemento O, Paknejad N, Manova-Todorova K, Welte K, Bromberg J, Peinado H, Lyden D (2014) Double-stranded DNA in exosomes: a novel biomarker in cancer detection. Cell Res 24: 766-769.

Ulivi P, Silvestrini R (2013) Role of quantitative and qualitative characteristics of free circulating DNA in the management of patients with non-small cell lung cancer. Cell Oncol (Dordr) 36: 439-448.

VAN Boerdonk RA, Brokx HA, Lee P, Kooi C, Postmus PE, Snijders PJ, Grünberg K, Thunnissen E, Sutedja TG, Daniels JM, Heideman DA (2013) Can quantifying free-circulating DNA in plasma be used to identify subjects with high-grade pre-invasive endobronchial lesions? Oncol Lett 5: 1591-1594.

Van der Drift MA, Hol BE, Klaassen CH, Prinsen CF, van Aarssen YA, Donders R, van der Stappen JW, Dekhuijzen PN, van der Heijden HF,
Thunnissen FB (2010) Circulating DNA is a non-invasive prognostic factor for survival in non-small cell lung cancer. Lung Cancer 68: 283-287. Vassilakopoulos T, Troupis T, Sotiropoulou C, Zacharatos P, Katsaounou P, Parthenis D, Noussia O, Troupis G, Papiris S, Kittas C, Roussos C, Zakynthinos S, Gorgoulis V (2001) Diagnostic and prognostic significance of squamous cell carcinoma antigen in non-small cell lung cancer. Lung Cancer 32: 137-144.

Vinayanuwattikun C, Winayanuwattikun $\mathrm{P}$, Chantranuwat $\mathrm{P}$, Mutirangura A, Sriuranpong V (2013) The impact of non-tumor-derived circulating nucleic acids implicates the prognosis of non-small cell lung cancer. J Cancer Res Clin Oncol 139: 67-76.

Wu Y, Du X, Xue C, Li D, Zheng Q, Li X, Chen H (2013) Quantification of serum SOX2 DNA with FQ-PCR potentially provides a diagnostic biomarker for lung cancer. Med Oncol 30: 737.

Yoon KA, Park S, Lee SH, Kim JH, Lee JS (2009) Comparison of circulating plasma DNA levels between lung cancer patients and healthy controls. J Mol Diagn 11: 182-185.

Zhang G, Xu Y, Lu X, Huang H, Zhou Y, Lu B, Zhang X (2009) Diagnosis value of serum B7-H3 expression in non-small cell lung cancer. Lung Cancer 66: 245-249.

This work is published under the standard license to publish agreement. After 12 months the work will become freely available and the license terms will switch to a Creative Commons AttributionNonCommercial-Share Alike 4.0 Unported License 